\title{
E-Learning for Educators in Digital Era 4.0
}

\author{
Mustakim Sagita ${ }^{1}$, Khairunnisa ${ }^{2}$ \\ ${ }^{1,2}$ English Education Study program, Universitas Jabal Ghafu, Indonesia \\ mustakim_sagita@unigha.ac.id
}

\section{Abstract}

In this Industrial 4.0 revolution era, technological advances become things that cannot be solved in human life. Teachers must learn better in learning, need to utilize optimal learning resources, this is important, because the effectiveness of learning is also included by the willingness and ability to utilize learning media, such as the web (google class). In this era students are required to have certain skills, besides those educators are also required to have several competencies that must be possessed so that the e-learning program that they run can run well. An educator or teacher must be able to learn to be there to learn, be creative and fun.

\section{Keywords}

Digital Era; education; usefulness of E-Learning, Teacher

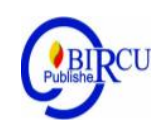

\section{Introduction}

The demand for teacher professionalism has a major impact on changes in education. Teachers are required to follow the development of technology so that the learning given to students is in accordance with the development in their environment. The technology used in learning can be a medium that is very helpful for both students and teachers in the learning process in the classroom. The use of appropriate learning media can foster interest in learning, even improve student learning outcomes (Daryanto in Simorangkir, 2018).

In this digital era the development of technology is developing very rapidly. This is because the world entered industry 4.0 where technology became the most basic thing in it. When the world undergoes a changing era, there are many things that also follow it or in other words, changes occur in several sectors of life. However, it is not just the changes that occur but the challenges go along with it. Angela Merkel (2014) argues that Industry 4.0 is a comprehensive transformation of all aspects of production in the industry through the merger of digital technology and the internet with conventional industries. It can be said that the 4.0 industrial revolution is based on digital. The development of technology and information has brought the current generation into the world of digital literacy. The digital age has become one with the current condition of society. This condition has caused many people to be easier, faster and have greater opportunities in finding various information. In addition, one of the benefits of information technology is being able to overcome the limitations of space and time. Workers in all fields during the Industrial Revolution 4.0 era are required to have digital skills, such as in the fields of development, economics and in education. In the field of education for example, an educator must understand digital mastery. Various kinds of technology should be applied in teaching in the classroom.

An educator needs to plan innovative, creative learning techniques using technologybased learning or Computer Assisted Instruction (Kristiawan, 2014). Various kinds of technology-based or digital learning resources that can be applied in the learning process 
But the fact is, we also have to admit that there are still competencies that are demands of the era of the Industrial Revolution 4.0 have not been well prepared. Many reasons why we have not been given the provision of competence in facing the Industrial Revolution 4.0 era. One of them is the use of E-Learning media. The use of e-learning or electronic-based learning is not something new to the ears. What happens in the field, the use of e-learning media has not been effective, there are still many teachers who use conventional classes. There are several reasons educators have not implemented it. It could be, as educators are also still stuttering about virtual technology, or we are adept at still reluctant to teach, or we have taught but the way is not right so the results are not optimal. Therefore, our awareness and enthusiasm is needed to improve the quality of learning so that our students become graduates who are ready to face the world of work in the Industrial Revolution 4.0 era.

This literature study has several formulations of the problems that will be investigated in this paper to find out how the teacher's attitude in utilizing technology in the learning process: 1. What is meant by e-learning? 2. What is the role and function of e-learning (google classroom) in the learning process, especially in the process of learning English? 3. How to use e-learning (google classroom) in the learning process, especially in the process of learning English? 4. What are the advantages and disadvantages of e-learning in the learning process, especially in the process of learning English? Writing purpose The author has several objectives in conducting this research, namely to find out several things: 1 . Understanding e-learning 2. What is the role and function of e-learning, especially in the process of learning English 3. How to use e-learning in the learning process, especially in the process of learning English 4. Strengths and weaknesses of e-learning in the learning process, especially in the process of learning English

\section{Research Method}

This writing methodology uses a literature study. The writer seeks and collects information relating to the formulation of the problem. Then the information obtained is analyzed and makes a written framework thus producing relevant information.

\section{Discussion}

The digital era is an era where the increasingly rapid development and technological competition in the world, do not be surprised if the learning media used are also increasingly sophisticated, one of which is through e-learning. E-Learning is a term that we can find in the world of computers or the internet.

The word e-learning consists of 2 (two) parts, namely "e" which means "electronic" or electronic and "learning" which means "learning". So the word e-learning can be interpreted as a learning system that uses electronic devices as a medium of learning. (Gartika R and Rita R, 2013: 27).

According to Hartley (2001) E-learning is a type of teaching and learning that allows the delivery of teaching materials to students using internet media, or other computer network media. This is in line with the opinion expressed according to Horton (2003) explaining elearning is web-based learning that can be accessed from the internet. Meanwhile Kamarga (2000) defines e-learning as learning activities delivered through computer electronic devices that obtain learning materials that meet their needs. 
From some of the above opinions it can be concluded that E-Learning is learning based on internet electronic technology that is used to facilitate receiving knowledge and improve student skills. According to Nursalam (2008: 135) E-learning has several characteristics, namely:

a. tilizing electronic technology services.

b. tilizing the advantages of computers (digital media and computer networks)

c. Sing self-learning materials which are then stored on a computer, so that they can be accessed by lecturers and students anytime and anywhere.

d. tilizing learning schedules, curriculum, learning progress results, and matters relating to education administration can be seen at any time on the computer.

E-learning is an innovation that can be utilized in the learning process, not only in the delivery of learning material but also changes in the abilities of various competencies of students. Through e-learning, students not only listen to material descriptions from educators, but also actively observe, do, demonstrate, and so on. Teaching material material can be visualized in various formats so that it is more interesting and more dynamic so that it can motivate students to go further in the learning process. (Hartanto, 2011)

\subsection{Benefits of Using E-Learning}

Rahmasari and Rismiati said that learning-learning activities had several benefits, namely: a. Through e-learning, students can access knowledge at any time without limit in time and place, b. Through e-learning, students can establish communication through the internet so that more knowledge can be obtained by them, c. Through e-learning, students learn easier and more enjoyable. d. Through e-learning, the learning process is more interactive and innovative, and d. Through e-learning, students are encouraged to explore through available webside, so that creativity and a sense of curiosity continue to grow. (Rahmasari and Rismiati, 2013: 69) Meanwhile Rohmah said several other benefits of learning activities using e-learning, namely: 1 . With e-learning, it can shorten learning time and make study costs more economical, 2. E-learning facilitates interaction between students and material, 3. Students can share information and can access learning materials at any time and over and over again, with such conditions that students can strengthen their mastery of learning materials, and 4. With e-learning the process of developing knowledge not only happens in the classroom, but with the help of computer equipment and networks, students can be actively involved in the teaching-learning process. (Rohmah, 2016) It can be said that e-learning has many benefits that can be applied in the learning process. With e-learning or digital learning, it is a technique in building students more comfortable in learning, when displayed a material that attracts students.

\subsection{The Role and Function of E-Learning in Learning process}

Technology plays an important role in the world of education, both in learning and teaching activities. In addition, e-learning has a very important function in learning activities, namely as a supplement (supplementary), complementary (complementary), and substitution (substitute).

1). Supplements (additional)

Students have freedom of choice, whether to use electronic learning materials or not. In this case, there is no obligation / obligation for students to access electronic learning materials. Accessing electronic learning materials is only as a teacher's appeal to students.

2). Complement (supplement)

Electronic learning materials are programmed to supplement learning materials received by students in the classroom, as enrichment for average-capable students, or remedial for students who are slow in their learning abilities. 


\section{3). Substitution (substitute)}

E-learning as a substitute is used in several universities in developed countries. Its purpose is to help make it easier for students to manage learning activities / lectures so that students can adjust their time and other activities with lecture activities. Students can choose a model of learning activities, namely face to face only, some face to face and in part through the internet, or completely through the internet.

Any alternative learning model chosen by students is not a problem in the assessment, meaning that all the models get the same recognition or assessment. This highly flexible situation is very helpful for students to accelerate the lecture process.

\subsection{Use of E-Learning (Google Classroom) in the Learning Process}

In the world of education, Indonesia is increasingly experiencing significant development. This development can be seen from the increasingly diverse learning methods used. The method used uses a lot of various media to improve the quality of learning outcomes, one of which is the use of media or technology-based or digital or internet-based methods is increasing (e-learning). Although the definition of e-learning is diverse, but in essence e-learning is learning utilizing electronic technology such as films, videos, LCDs, slide projectors, etc. and utilizes internet facilities that are online as their main instruments as media / facilities in the presentation of material.

Basically learning in class should be adjusted to his time. An educator or teacher must be able to capture the opportunities that exist in order to create creative, innovative and fun learning. Mulyasa said that teachers who are professional in every learning, need to utilize learning resources optimally, this is very important, because the effectiveness of learning is also determined by the willingness and ability to utilize learning resources. Learning resources are very necessary to find information. To obtain information must be sought from information sources. One source of information is the internet. The internet is a multi-field information center. All aspects of life both positive and negative impacts can be accessed and obtained from the internet. (Mulyasa, 2005: 183)

However, not only students are required to master certain skills, an educator is also required to have some competencies that he must have so that the e-learning program that he runs can work well. In implementing e-learning, there are three basic competencies that educators must possess to carry out e-learning learning models, namely:

1. The ability to make instructional designs (instructional designs) in accordance with the pedagogical rules as outlined in the learning plan,

2. Mastery of technology in learning, namely the use of the internet as a source of learning in order to get up to date and quality teaching material,

3. Mastery of learning materials (subject metter) in accordance with their field of expertise.

(Hartanto, 2011)

The development of information and communication technology (ICT) that produces the internet with web-based learning is a learning activity that utilizes website media that can be accessed through the internet network. Web-based learning is one type of application of electronic learning (e-learning). One of them is Google Classroom. Google Classrooms is also an e-learning media because Google classroom is the latest feature of the google app for education that can be utilized by teachers and students in the learning process. According to Afrianti (2018: 17) Google Classroom or Google classrooms is a mixed learning porch for the scope of education that can facilitate teachers in making, sharing and classifying any paperless assignments. So, it can be said to be very efficient because it can be accessed anywhere and anytime. Based on the official website of Google (in Afrianti. (2018: 12), Google Classroom provides several benefits such as: 1) Classes can be prepared easily; 
instructors can prepare classes and invite students and teaching assistants. Then in the class stream, they can share information such as assignments, announcements and questions; 2) Save time and paper; teachers can create classes, assign assignments, communicate and do management, all in one place; 3) Better management; students can see assignments on the assignment page, in the class stream or on the class calendar. All material is automatically stored in the Google Drive folder; 4) Improving communication and input; the teacher can make assignments, send announcements and start class discussions directly. Students can share material with each other and interact in class flow via email. Teachers can also quickly see who has and hasn't completed an assignment, and immediately provides real-time grades and input; 5) Can be used with the application you are using; the class functions with Google Documents, Calendar, Gmail, Drive and Forms; 6) Safe and affordable; classes are provided free of charge. Classes do not contain advertising and never use student content or data for advertising purposes. In addition, Google Classroom can be accessed in 2 ways, namely through websites and applications.

Google Classroom as a learning media that is also suitable to be applied as the use of elearning because it is very efficient for educators and students who do not require face to face learning, and can be accessed via mobile phones.

From the above explanation, Google Classroom as a learning media is expected to be utilized very well. Besides making it easier for students to absorb learning material properly and effectively, it also invites educators and participants to be involved in the advancement of the digital era, especially the 4.0 revolution, so children are prepared to face technological developments. increasingly sophisticated.

\subsection{Strengths and Weaknesses of Use E-Learning}

In each learning method, it is inseparable from the advantages and disadvantages. As stated by the following opinions. The advantage of E-learning is to provide flexibility, interactivity, speed, visualization through various strengths from each media (Sujana, 2005: 253)

Meanwhile according to (Elangoan, 1999; Soekartawi, 2002; Mulvihil, 1997; Utarini, 1997) in (Yazdi, 2012), among others. First, the availability of e-moderating facilities where teachers and students can communicate easily through regular internet facilities or whenever communication activities are carried out without being limited by distance, place and time. Secondly, teachers and students can use teaching materials or study instructions which is structured and scheduled through the internet, so the two can assess each other to what extent the teaching material is studied. Third, students can study or review teaching materials at any time and anywhere if needed, remembering instructional materials stored on a computer. Fourth, if students need additional information relating to the material learned, he can access the internet more easily. Fifth, both teachers and students can carry out discussions via the internet that can be followed by a large number of participants, thereby increasing knowledge and broader insights. Keenam, Changing the role of students from being normally passive to active. Seventh, relatively more efficient.

Nevertheless the use of the internet for learning or e-learning is inseparable from a variety of shortcomings. Various criticisms (Bullen, 2001, Beam, 1997) in (Yazdi, 2012), among others. First, Lack of interaction between teacher and student or even between students themselves. This lack of interaction can slow the formation of values in the learning and teaching process. Second, the tendency to ignore the academic aspects or social aspects and vice versa encourage the growth of business / commercial aspects. Third, the learning and teaching process tends towards training rather than education. Fourth, Changing the role of the teacher from initially mastering conventional learning techniques, is now also required to know learning techniques Fifth, students who do not have the motivation to learn the high 
tends to fail. Sixth, Not all places are available internet facilities. Seventh, Lack of personnel who know and have internet skills. Eighth, Lack of mastery of computer language.

This makes us aware as users to be able to take advantage of existing advantages as well as possible and more selective in their use.

\section{Conclusion}

The digital era of the industrial revolution 4.0 which is currently being experienced requires us to face it. With a variety of increasingly sophisticated digital-based technologies that we must master or at least follow the current, E-learning is one that we can use in the world of learning in the classroom.

As educators we are also required to be more creative and innovative in delivering learning material in class, because the task or responsibility of an educator is inseparable also in producing children who have competence in them, one of them in mastering digital-based technology so that they are able to deal with world developments. more rapidly. The rapid development of information and communication technology (ICT) produces the internet with web-based learning. Learning is one type of application of the concept of e-learning. The simplest web-based learning is Website (Google Classroom) which can be used to present learning materials, discussions, assignments, and others related to learning activities.

\section{References}

Afrianti, W.E. (2018). Penerapan Google Classroom dalam Pembelajaran Akuntansi. Yogyakarta: Universitas Islam Indonesia.

Gartika Rahmasari and Rita Rismiati. (2013). e-learning Pembelajaran Jarak Jauh di SMA. Bandung: Penerbit Yrama Widya.

Hartanto, Wiwin. Penggunaan E- Learning Sebagai Media Pembelajaran.UNEJ.

Hartley, Darin E., (2001). Selling E-Learning, American Society for Training and Development.

Horton, William dan Horton, Katherine.E-Learning Tools and Technologies: A Consumer Guide for Trainers, Teachers, Educators, and Instructional Designers. USA: Wiley Publishing, Inc. 2003.

Kamarga. (2000). Sistem E-Learning. Jakarta: Salemba Empat.

Kristiawan, M. (2014). A Model for Upgrading Teachers Competence on Operating Computer as Assistant of Instruction. Global Journal of Human- Social Science Research.

Merkel, A. (2014). Speech by Federal Chancellor Angela Merkel to the OECD Conference. https://www.bundesregierung.de/Content/EN/Reden/2014/2014-02-19-oecd-merkelparis_en.html,Accessed 28 March 2020.

Mulyasa.(2010). Menjadi Guru Profesional Menciptakan Pembelajaran Kreatif dan Menyenangkan. Bandung: PT Remaja Rosdakarya.

Nursalam and Ferry Efendi. (2008). Pendidikan dalam Keperawatan. Jakarta: Salemba Medika.

Simorangkir, F. (2018). Effectiveness of Helped Mathematical Learning Media of Lectora Inspire on The Number Sense Ability of Fifth Grade Students of Elementary School in Substrate Materials. Budapest International Research and Critics Institute (BIRCIJournal), p. 352-358. 